\title{
The Biosorption Capacity of Saccharomyces Cerevisiae for Cadmium in Milk
}

\author{
Ramona Massoud ${ }^{1}$ (D), Kianoush Khosravi-Darani ${ }^{2, *(\mathbb{D})}$, Anousheh Sharifan ${ }^{3}$, \\ Gholam Hassan Asadi ${ }^{3}$ and Habibollah Younesi 4 (D) \\ 1 Department of Food Science and Technology, Standard Organization, 1476845711 Tehran, Iran; \\ rm8059@yahoo.com \\ 2 Research Department of Food Technology, National Nutrition and Food Technology Research Institute, \\ Faculty of Nutrition Sciences and Food Technology, Shahid Beheshti University of Medical Sciences, \\ 193954741 Tehran, Iran \\ 3 Department of Food Science and Technology, Science and Research branch, Islamic Azad University, \\ 147749385 Tehran, Iran; a_sharifan2000@yahoo.com (A.S.); asadi.srb@gmail.com (G.H.A.) \\ 4 Department of Environment Science, Faculty of Natural resources and Marine Sciences, \\ Tarbiat Modares University, 14115111 Noor, Iran; hunesi@yahoo.com \\ * Correspondence: k.khosravi@sbmu.ac.ir; Tel.: +98-21-22086348
}

Received: 1 September 2020; Accepted: 10 September 2020; Published: 17 September 2020

\begin{abstract}
This study aimed to evaluate the capacity of Saccharomyces cerevisiae for Cadmium absorption in milk. Nowadays, one of the most serious problems of the industrialized world is heavy metal pollution. Applying microorganisms as novel biotechnology is very useful, especially in foodstuffs. Among the biosorbents used for heavy metal removal, Saccharomyces cerevisiae has received increasing attention due to its popularity in the food industry. In this regard, the effects of some important factors such as the initial metal concentration, biomass concentration and contact time on the biosorption capacity of Saccharomyces cerevisiae were studied. The biosorption was analyzed by the inductively coupled plasma mass spectrometer (ICP-MS). The maximum cadmium (Cd) removal (70\%) was at $80 \mu \mathrm{g} / \mathrm{L}$ of Cd concentration in milk samples containing $30 \times 10^{8} \mathrm{CFU}$ Saccharomyces cerevisiae at the end of storage time (the 4th day). There were no significant differences in the sensory and physicochemical properties $(\mathrm{pH}$, acidity and density) of milk samples during storage $(p<0.05)$. The isotherm studies were followed by two popular models, Langmuir and Freundlich, and the results showed a better fit to the Langmuir isotherm. Altogether, the results of this study demonstrate that the approach of using this valuable yeast could be applied for food detoxification and producing healthier foodstuffs.
\end{abstract}

Keywords: Saccharomyces cerevisiae; biosorption; milk; ICP-MS; isotherm; sensory evaluation

\section{Introduction}

Toxic metal contamination is a serious environmental problem all around the world due to the fast development of industries such as fuel, pesticides and mining. Their wastes discharge metals into the environment directly or indirectly [1,2]. These toxic metals can enter the food chain and then into our bodies [3]. Cadmium (Cd) is one of the most toxic metals in this regard [4]. Milk is a valuable food source for humans and animals. It has nearly all the essential nutrients for growth [5]. According to the World Health Organization (WHO), the maximal allowed concentration values for Cd in milk are less than $10 \mu \mathrm{g} / \mathrm{L}[6]$.

Some reports have shown $\mathrm{Cd}$ contamination of milk around the world, and unfortunately, in some places, it is more than the permissible level: Turkey [7], China [8], Iraq [9] and Iran [10,11]. 
Common techniques for heavy metal removal from aqueous solutions, like ion exchange, chemical precipitation, membrane technologies, electrochemical treatment and using activated carbon, are expensive and also not effective for use in foodstuffs [12,13].

Biosorption, as a green technology, is the process of metal-binding from aqueous solution to the surface of a microorganism. The mechanism occurs through the absorption of metal ions to functional groups on the cell wall of the biomass [12]. It is a cheap, eco-friendly and fast technique [14]. Biosorpton is a process that the heavy metals trap into the cell wall's active site [12]. The heavy metal removal takes place through various mechanisms. The functional groups of the cell wall of S. cerevisiae, such as hydroxyl and carboxyl, are responsible for the biosorption technique. They are the main agents for metals to be attached during the mechanism. Moreover, the heavy metal intracellular accumulation occurs in the cell wall and metals are able to attach to the cell molecules [13-15].

In the biosorption method, various microorganisms like yeasts, bacteria, algae and fungi are applied. They possess some advantages, such as being cheap and practical for foodstuffs $[13,15]$.

The unique yeast "Saccharomyces cerevisiae" is commonly used in the bakery and brewery industries. It is an economically available biosorbent [16]. There are some studies about using this yeast for heavy metal biosorption [17-21].

Our study aims to evaluate the capacity of S. cerevisiae for $\mathrm{Cd}$ absorption in milk. Therefore, the effects of three main factors; initial metal concentration, biomass concentration and contact time on the biosorption capacity of $S$. cerevisiae were studied. These factors were chosen through the previous studies of heavy metal bioremoval [19-22] and also based on the results of our research team. This technique would be useful in the case of emergencies in the food and beverage industry.

\section{Materials and Methods}

\subsection{Preparation of the Biomass}

The S. cerevisiae (PTCC-5020) was purchased from the Science Research and Technology Department, Tehran, Iran. Glucose, yeast extract, $\left(\mathrm{NH}_{4}\right)_{2} \mathrm{SO}_{4}, \mathrm{~K}_{2} \mathrm{HPO}_{4}, \mathrm{MgSO}_{4}$ and $\mathrm{KH}_{2} \mathrm{PO}_{4}$ were combined with the yeast culture medium and then autoclaved at $121^{\circ} \mathrm{C}$ for $20 \mathrm{~min}$. The medium was inoculated with $S$. cerevisiae after cooling followed by $20 \mathrm{~h}$ shaking at $70 \mathrm{rpm}$ and then incubated at $30^{\circ} \mathrm{C}$. The biomass colonies were counted and the mean of $30 \times 10^{8} \mathrm{CFU} / \mathrm{mL}$ was obtained through the dilution method; the seed culture $(1 \mathrm{~mL})$ was diluted in a ratio of 1:10 with $\mathrm{NaCl}$ with serial dilutions (10 times). Then, the dilution $(1 \mathrm{~mL})$ was added to the nutrient agar medium by pour plate method and incubated for $72 \mathrm{~h}$ at $30^{\circ} \mathrm{C}$ for $72 \mathrm{~h} \mathrm{[23].}$

\subsection{Chemicals}

All chemicals were provided from Merck company (Darmstadt, Germany) and Cd standard solution from Accu Trace company (Coatesville, PA, USA). All the containers were acid-washed by $\mathrm{HNO}_{3}(15 \% \mathrm{v} / \mathrm{v})$ overnight and then rinsed with distilled water.

\subsection{Sample Preparation}

Each sample was prepared for milk $(50 \mathrm{~mL})$ with levels of S. cerevisiae $\left(10 \times 10^{8}\right.$ to $\left.50 \times 10^{8} \mathrm{CFU} / \mathrm{mL}\right)$ and different initial Cd concentrations $(40,50,60,70,80 \mu \mathrm{g} / \mathrm{L})$ and stored in the fridge for 4 days. Then the effect of 3 variables-initial metal concentration $(40-80 \mu \mathrm{g} / \mathrm{L})$, biomass concentration $\left(10-50 \times 10^{8} \mathrm{CFU} / \mathrm{mL}\right)$ and contact time (1-4 days) - on the biosorption capacity of $S$. cerevisiae were studied.

\subsection{Physicochemical Analysis}

The $\mathrm{pH}$, acidity and density of milk samples were determined according to AOAC methods [23]. The $\mathrm{pH}$ value of milk samples was evaluated with a $\mathrm{pH}$ meter (Metrom, Switzerland) at room temperature. The titratable acidity was determined by titration method; milk sample $(10 \mathrm{~mL})$ was 
titrated by $\mathrm{NaOH}$ solution $(0.1 \mathrm{~N})$ and adding phenolphthalein as an indicator. The Lactodensimeter (Alla, France) was used to measure the density of milk samples [23].

\subsection{Sensory Analysis}

The sensory analysis was evaluated during storage time (1st to 4th day) by 10 trained panelists [24]. Milk samples were analyzed for consistency, color, odor and overall acceptability. The samples were scored on a 9-point hedonic scale. The scores were from 1 (extreme dislike) to 9 (extreme like). Mean values $( \pm \mathrm{SD})$ were calculated from the panelists' scores of each sample.

\subsection{Central Composite Design (CCD)}

The 3 variables-initial Cd concentration, S. cerevisiae biomass and contact time-have significant effects on Cd removal. In this study, CCD was used to find the optimal conditions of Cd biosorption with the experimental factor levels as shown in Table 1.

Table 1. Levels of the main variables for the central composite design.

\begin{tabular}{lccccc}
\hline \multirow{2}{*}{ Main Variable } & \multicolumn{5}{c}{ Range and Level } \\
\cline { 2 - 6 } & $-\boldsymbol{\alpha}(\mathbf{- 1 . 6 )}$ & $\mathbf{- 1}$ & $\mathbf{0}$ & $\mathbf{+ 1}$ & $\boldsymbol{+} \boldsymbol{\alpha}(\mathbf{+ 1 . 6 )}$ \\
\hline S. cerevisiae biomass dosage $\left(\times 10^{8} \mathrm{CFU}\right)$ & 10 & 20 & 30 & 40 & 50 \\
Initial Cd concentration) $\mu \mathrm{g} / \mathrm{L})$ & 40 & 50 & 60 & 70 & 80 \\
Contact time (day) & 0 & 1 & 2 & 3 & 4 \\
\hline
\end{tabular}

\subsection{ICP-MS Analysis}

The inductively coupled plasma mass spectrometer (ICP-MS, England) was applied in this study, with a standard torch, a cross-flow nebulizer and a quartz spray chamber. It was tuned before each experiment started. All the samples were put in microwave $1200 \mathrm{~W}$ (Milestone Micro oven) to be digested with segmented rotor MPR-600 [25].

\subsection{Removal Evaluation}

The milk samples containing S. cerevisiae and $\mathrm{Cd}$ were digested in the microwave and then centrifuged $($ at $2000 \times g$ ) for $15 \mathrm{~min}$. The supernatant was injected into the ICP-MS for Cd residual determination. This was measured by using the ICP-MS. All the trials were repeated in triplicate.

The Cd removal efficiency (\%) was calculated by Equation (1) [26]:

$$
\% \text { Removal }=100\left(\mathrm{Co}-\mathrm{C}_{\mathrm{f}}\right) / \mathrm{Co}
$$

where $C_{0}(\mu \mathrm{g} / \mathrm{L})$ : is the initial Cd concentration in solution; $C_{f}(\mu \mathrm{g} / \mathrm{L})$ : is the final Cd concentration in solution.

\subsection{Absorption Isotherm}

The biosorption isotherm was evaluated by adding the biosorbent (S. cerevisiae) to the milk samples with initial Cd concentrations (20-100 $\mu \mathrm{g} / \mathrm{L})$. After biosorption, the remaining $\mathrm{Cd}$ was determined by ICP-MS. The biosorption experiments were repeated three times.

\subsection{Statistical Analysis}

The statistical analysis was performed by MINITAB statistical software (version 14). The statistics data were provided by analysis of variance (ANOVA). The data are presented as the mean value $\pm \mathrm{SD}$ during storage days. The $p$-values below 0.05 were statistically significant. 


\section{Results}

\subsection{The Effect of Initial Metal Concentration}

The effect of initial Cd concentration $(40,50,60,70,80 \mu \mathrm{g} / \mathrm{L})$ on the bioremoval efficiency was investigated (Figure 1a). The results showed that by increasing the $\mathrm{Cd}$ concentrations, the absorption improved. The highest Cd removal (70\%) was observed at the initial metal concentration of $80 \mu \mathrm{g} / \mathrm{L}$.

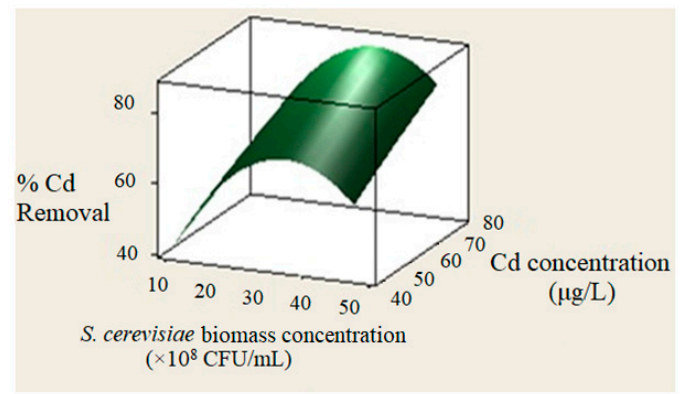

(a)

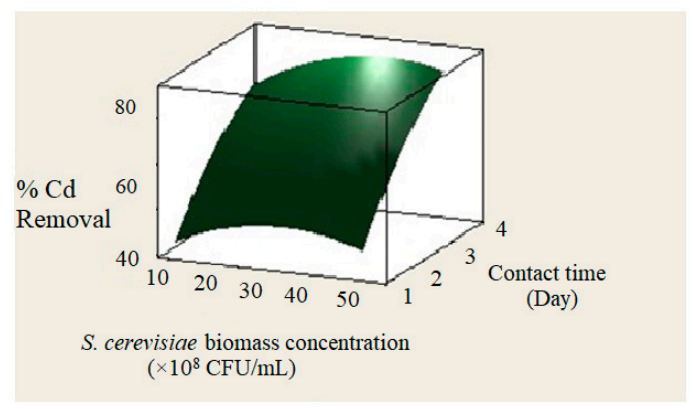

(b)

Figure 1. The effect of initial Cadmium (Cd) concentration on bioremoval (a); the effect of biomass concentration initial on bioremoval (b).

\subsection{The Effect of Contact Time}

In this study, the $\mathrm{Cd}$ biosorption was evaluated during the contact times from 1 to 4 days. Figure $1 \mathrm{~b}$ shows that $\mathrm{Cd}$ removal by $S$. cerevisiae increased as time passed. As shown, the maximum removal of $\mathrm{Cd}$ occurred on the 4th day. By increasing time up to 8 days, the yeast count was enhanced as the removal was nearly constant. Table 2 shows the yeast count and the bioremoval levels during 8 days of storage.

Table 2. The bioremoval level of $\mathrm{Cd}$ in milk samples during storage.

\begin{tabular}{lccc}
\hline & \multicolumn{3}{c}{ Storage Time (Day) } \\
\cline { 2 - 4 } & $\mathbf{1}$ & $\mathbf{4}$ & $\mathbf{8}$ \\
\hline S. cerevisiae biomass (CFU/mL) & $10^{8}$ & $10^{8}$ & $10^{9}$ \\
Total count $(\mathrm{CFU} / \mathrm{mL})$ & $10^{12}$ & $10^{12}$ & $10^{15}$ \\
Cd bioremoval $(\%)$ & $45.51^{\mathrm{a}}$ & $70.10^{\mathrm{b}}$ & $70.21^{\mathrm{b}}$ \\
\hline
\end{tabular}

Different letters are significantly different $(p<0.05)$.

\subsection{The Effect of Biomass Concentration}

As shown in Figure $1 \mathrm{a}, \mathrm{b}$, by increasing $S$. cerevisiae biomass concentration from 10 up to $50 \times 10^{8} \mathrm{CFU} / \mathrm{mL}$, the removal efficiency enhanced. The optimum level of $S$. cerevisiae biomass concentration was $30 \times 10^{8} \mathrm{CFU}$ with the highest removal amount of $70 \%$.

\subsection{Physicochemical Evaluation}

There was a slight reduction in $\mathrm{pH}$ values and a rise in titratable acidity of the milk samples. Additionally, the density level was nearly constant. However, the differences were not significant in the milk samples $(p>0.05)$ (Table 2$)$.

\subsection{Sensory Evaluation}

Table 3 also represents the results of sensory analysis during the storage of milk samples. There were no significant differences in the consistency, smell and color of these milk samples during 
time intervals with control samples $(p<0.05)$. Additionally, the overall acceptance of milk samples had no significant difference throughout the storage period $(p<0.05)$.

Table 3. Physicochemical and sensory properties of milk samples during storage.

\begin{tabular}{|c|c|c|c|c|c|c|}
\hline \multirow{3}{*}{ Storage Time (Day) } & \multicolumn{6}{|c|}{ S. cerevisiae Biomass Concentration (CFU/mL) } \\
\hline & \multicolumn{2}{|c|}{ Control } & \multicolumn{2}{|c|}{$10 \times 10^{8}$} & \multicolumn{2}{|c|}{$50 \times 10^{8}$} \\
\hline & 1 & 4 & 1 & 4 & 1 & 4 \\
\hline \multicolumn{7}{|c|}{ Physicochemical properties } \\
\hline $\mathrm{pH}$ & $6.70 \pm 0.01^{\mathrm{a}}$ & $6.67 \pm 0.05^{a}$ & $6.78 \pm 0.01^{a}$ & $6.67 \pm 0.07^{\mathrm{a}}$ & $6.80 \pm 0.07^{\mathrm{a}}$ & $6.71 \pm 0.07^{\mathrm{a}}$ \\
\hline Acidity (\% lactic acid) & $0.14 \pm 0.01^{\mathrm{a}}$ & $0.15 \pm 0.05^{\mathrm{a}}$ & $0.14 \pm 0.07^{\mathrm{a}}$ & $0.15 \pm 0.07^{\mathrm{a}}$ & $0.14 \pm 0.07^{\mathrm{a}}$ & $0.16 \pm 0.07^{\mathrm{a}}$ \\
\hline Density $\left(\mathrm{g} / \mathrm{cm}^{3}\right)$ & $1.01 \pm 0.01^{\mathrm{a}}$ & $1.01 \pm 0.05^{\mathrm{a}}$ & $1.02 \pm 0.01^{\mathrm{a}}$ & $1.03 \pm 0.05^{\mathrm{a}}$ & $1.02 \pm 0.07^{\mathrm{a}}$ & $1.02 \pm 0.05^{\mathrm{a}}$ \\
\hline \multicolumn{7}{|c|}{ Sensory property } \\
\hline Color & $7.99 \pm 0.07^{a}$ & $7.97 \pm 0.05^{a}$ & $7.97 \pm 0.07^{a}$ & $7.89 \pm 0.07^{\mathrm{a}}$ & $7.90 \pm 0.05^{\mathrm{a}}$ & $7.85 \pm 0.05^{\mathrm{a}}$ \\
\hline Smell & $7.99 \pm 0.05^{\mathrm{a}}$ & $7.96 \pm 0.05^{\mathrm{a}}$ & $7.95 \pm 0.05^{\mathrm{a}}$ & $7.66 \pm 0.05^{\mathrm{a}}$ & $7.95 \pm 0.07^{\mathrm{a}}$ & $7.52 \pm 0.05^{\mathrm{a}}$ \\
\hline Consistency & $7.98 \pm 0.05^{\mathrm{a}}$ & $7.98 \pm 0.07^{a}$ & $7.97 \pm 0.05^{a}$ & $7.94 \pm 0.07^{\mathrm{a}}$ & $7.90 \pm 0.05^{\mathrm{a}}$ & $7.88 \pm 0.05^{\mathrm{a}}$ \\
\hline Overall acceptance & $7.98 \pm 0.07^{\mathrm{a}}$ & $7.95 \pm 0.05^{a}$ & $7.98 \pm 0.07^{a}$ & $7.95 \pm 0.05^{a}$ & $7.98 \pm 0.07^{a}$ & $7.90 \pm 0.07^{\mathrm{a}}$ \\
\hline
\end{tabular}

\subsection{Isotherm Studies}

The capacity of S. cerevisiae biomass concentration $\left(10^{8} \mathrm{CFU} / \mathrm{mL}\right)$ for $\mathrm{Cd}$ biosorption was determined at $\mathrm{Cd}$ initial concentrations $(20,40,60,80$ and $100 \mu \mathrm{g} / \mathrm{L})$ via two popular biosorption isotherms; Langmuir and Freundlich models. The regression coefficient $\left(R^{2}\right)$ represents the better isotherm model for Cd biosorption by S. cerevisiae.

The Langmuir equation is as the Equation (2) [27]:

$$
\mathrm{C}_{\mathrm{e}} / \mathrm{Q}_{\mathrm{e}}=1 /\left(\mathrm{K} * \mathrm{Q}_{\max }\right)+\mathrm{C}_{\mathrm{e}} / \mathrm{Q}_{\max }
$$

where Qe $(\mu \mathrm{g} / \mathrm{L})$ is the Cd amount in the absorbing process, $\mathrm{Ce}(\mu \mathrm{g} / \mathrm{L})$ is the Cd equilibrium concentration in milk, Qmax $(\mu \mathrm{g} / \mathrm{L})$ is the maximum Cd absorption level. $\mathrm{KL}(\mathrm{L} / \mu \mathrm{g})$ is the Langmuir constant. The Freundlich equation is as the following Equation (3) [28]:

$$
\operatorname{LnQ}_{e}=\operatorname{LnK}_{\mathrm{f}}+1 / n \operatorname{LnC}_{e}
$$

where $\mathrm{n}$ and $\mathrm{K}_{\mathrm{f}}$ are the Freundlich constants. The Langmuir and Freundlich parameters are shown in Table 4.

Table 4. Langmuir and Freundlich isotherm parameters for Cd removal.

\begin{tabular}{cccccc}
\hline \multirow{2}{*}{ Cd initial Concentration $(\mu \mathrm{g} / \mathrm{L})$} & \multicolumn{3}{c}{ Langmuir Model $^{\dagger}$} & \multicolumn{2}{c}{ Freundlich Model $^{\S}$} \\
\cline { 2 - 6 } & Ce & Qe & Ce/Qe & Ln Qe & Ln Ce \\
\hline 20 & 13.4 & 6.6 & 2.033 & 1.887 & 2.595 \\
40 & 23.2 & 16.8 & 1.381 & 2.821 & 3.144 \\
60 & 27 & 33 & 0.818 & 3.256 & 3.269 \\
80 & 28 & 51 & 0.522 & 3.889 & 3.263 \\
100 & 28 & 70 & 0.389 & 4.254 & 3.321 \\
\hline
\end{tabular}

${ }^{\dagger} \mathrm{R}^{2}$ for Langmuir model was obtained as $0.9186 .{ }^{\S} \mathrm{R}^{2}$ for Freundlich model was obtained as 0.8587 .

As Table 3 shows, both correlation coefficients were high in Langmuir and Freundlich isotherm models. By the comparison of calculated $\mathrm{R}^{2}$ values, it was revealed that the Langmuir isotherm model showed a better fit than the Freundlich model. 


\section{Discussion}

As shown in Figure 1a,b, by rising the biomass concentration up to $30 \times 10^{8} \mathrm{CFU}$, the absorption rate increased. The yeast of $S$. cerevisiae has a high biosorption affinity for heavy metals $[29,30]$. This trend is due to the carboxyl, hydroxyl and amino groups of the cell wall as the main responsible for the heavy metals' absorption [31-33]. As the number of metal ions increased, their absorption to the surface of the S. cerevisiae increases; therefore, higher biosorption would be observed [20,34,35]. By enhancing the $S$. cerevisiae biomass concentrations, the biosorption increases because of the more available binding sites for metal ions and therefore more binding combinations [36].

In addition, by increasing Cd concentration from 40 to $100 \mu \mathrm{g} / \mathrm{L}$, the biosorption yield increased (Figure 1a). Similar to our study results, Hadiani et al. [20] reported that Cd removal by S. cerevisiae increased with a rising Cd level (25 to $80 \mu \mathrm{g} / \mathrm{L})$. Ghorbani et al. [37] observed the Cd bioremoval by S. cerevisiae ( $2.13 \mathrm{~g} / \mathrm{L})$ at the concentration of $26.46 \mathrm{mg} / \mathrm{L}$. Additionally, Peng et al. [38] showed that $\mathrm{Cu}$ absorption by $\mathrm{S}$. cerevisiae increased by increasing the metal from 40 to $120 \mathrm{mg} / \mathrm{L}$. As shown in Figure $1 \mathrm{~b}, \mathrm{Cd}$ absorption is enhanced by rising contact time from day $1-4$. With time passing, more $\mathrm{Cd}$ ions would attach to $S$. cerevisiae receptor sites on the surface [39]. The findings of this study are in accordance with Hadiani et al. [20], who observed increasing mercury biosorption by S. cerevisiae from 24-48 h and Hatami Fard and Mehrnia [34] who reported more mercury absorption after 4 days. Like the above studies, in this study, the highest Cd removal efficiency $(70 \%)$ was observed at the $\mathrm{Cd}$ concentration of $80 \mu \mathrm{g} / \mathrm{L}$ and the biomass of $30 \times 10^{8} \mathrm{CFU}$ on the 4th day of storage. Prolongation of the experiment is recommended to evaluate further removal of heavy metal over a longer exposure. Additionally, it should be taken into account that in the case of spoilage of milk with bacterial cells or high initial microbial loading of milk, the rate of bio-decontamination could be quite different from this report.

Additionally, Table 3 shows that the absorption increased by increasing the initial concentration of $\mathrm{Cd}$, as more initial concentration prepared more contact sites for absorbance and Cd [34]. Comparing both $\mathrm{R}^{2}$ values in Langmuir and Freundlich isotherm models shows that the Langmuir model has a better fit, which confirms that the Langmuir equation is correct for monolayer absorption on a surface with similar sites. The higher $\mathrm{R}^{2}$ in the Langmuir model confirms that the $\mathrm{Cd}$ absorption by $S$. cerevisiae in our study obeys this model.

\section{Conclusions}

In this study, three important variables- $\mathrm{Cd}$, biomass concentration and the contact time for $\mathrm{Cd}$ bioremoval by S. cerevisiae - were evaluated. Our findings showed the highest level of $\mathrm{Cd}$ biosorption (70\%) observed in the S. cerevisiae concentration of $30 \times 10^{8} \mathrm{CFU}$ and $\mathrm{Cd}$ amount of $80 \mu \mathrm{g} / \mathrm{L}$ on the 4th day. The ability of $S$. cerevisiae was not studied in higher concentration (ppm) of $\mathrm{Cd}$ and in presence of other heavy metals in the effluents in foodstuffs. This study shows the ability of this valuable yeast for $\mathrm{Cd}$ remediation in very low concentrations ( $\mathrm{ppb}$ ) from milk with no changes in physicochemical ( $\mathrm{pH}$, acidity and density) and sensorial acceptability. S. cerevisiae is a desirable and eco-friendly biosorbent for toxic metal bioremediation from food and water resources. These findings open the window for the evaluation of the capacity of heavy metal binding by S. cerevisiae in milk. There is a need for more studies in this field to reduce the toxic effects of heavy metals in food and drink.

Author Contributions: Conceptualization, R.M., K.K.-D.; Software, A.S.; Formal Analysis, R.M., H.Y. and A.S.; Writing-Original Draft Preparation, R.M.; Writing-Review \& Editing, K.K.-D., A.S. and G.H.A.; Supervision, K.K.-D. and A.S. All authors have read and agreed to the published version of the manuscript.

Funding: This research received financial support of Shahid Beheshti University of Medical Sciences for grant Number 22408.

Acknowledgments: We are grateful to the National Nutrition and Food Technology Research Institute (NNFTRI) of Iran for supporting this study. Also we like to thank Zoghi for her kind assistance.

Conflicts of Interest: The authors declare no conflict of interest. 


\section{References}

1. Weldeslassi, T.; Balwant, H.; Oves, M. Chemical Contaminants in Soil. Air and Aquatic Ecosystem. Mod. Age Environ. Prob. Rem. 2017, 25, 1-22.

2. Doležalová Weissmannová, H.D.; Miho`cová, S.; Chovanec, P.; Pavlovský, J. Potential Ecological Risk and Human Health Risk Assessment of Heavy Metal Pollution in Industrial Affected Soils by Coal Mining and Metallurgy in Ostrava. Czech Republic Int. J. Environ. Res. 2019, 16, 4495. [CrossRef] [PubMed]

3. Kanwal, R.; Fiz, F.; Iqra, W.; Muhammad, S.; Hamid, A. Prevalence of exposure of heavy metals and their impact on health consequences. J. Cell. Biochem. 2019, 119, 157-184.

4. Ostroumov, S.A.; Tropin, I.V.; Kiryushin, A.V. Removal of Cadmium and Other Toxic Metals from Water: Thermophiles and New Biotechnologies. Rus. J. Gen. Chem. 2018, 88, 2962-2966. [CrossRef]

5. Ametaj, B.N. Introducing Dairy: A Transdisciplinary Journal to Advance Understanding of Dairy Nutrition, Health and Productivity, Welfare and Well-Being as Well as Milk Synthesis-Composition and Health Effects of Its Products. Dairy 2018, 1, 1. [CrossRef]

6. WHO (World Health Organization). International Standards for Drinking Water, 5th ed.; WHO Press, World Health Organization: Geneva, Switzerland, 2010.

7. Ayar, A.; Sert, D.; Akın, N. The trace metal levels in milk and dairy products consumed in middle Anatolia-Turkey. Environ. Monitor. Assess. 2015, 152, 1-12. [CrossRef]

8. Qin, L.; Wang, X.; Li, W.; Tong, X.; Tong, W. The minerals and heavy metals in cow's milk from China and Japan. J. Health Sci. 2009, 55, 300-305. [CrossRef]

9. Alani, M.S.; Al-Azzawi, M.N. Assessment of Lead Cadmium and Copper concentrations in Raw Milk Collected from different location in Iraq. Iraq J. Sci. 2016, 56, 350-355.

10. Nejatolahi, M.; Mehrjo, F.; Sheykhi, A.; Bineshpor, M. Lead Concentrations in Raw Cows' Milk from Fars Province of Iran. Am. J. Food Nutr. 2014, 2, 92-94.

11. Najarnezhad, V.; Akbarabadi, M. Heavy metals in raw cow and ewe milk from north-east Iran. Food Add. Contamin. 2013, 12, 2-6. [CrossRef]

12. Katarzyna, C.; Marcin, M. Green analytical methods of metals determination in biosorption studies. Trends Anal. Chem. 2019, 116, 254-265.

13. Wang, J.L.; Chen, C. Biosorption of heavy metals by Saccharomyces cerevisiae a review. Biotechnol. Adv. 2006, 24, 427-451. [CrossRef]

14. Gupta, V.K.; Nayak, A.; Agarwal, S. Bioadsorbents for remediation of heavy metals: Current status and their future prospects. Environ. Eng. Res. 2015, 20,1-18. [CrossRef]

15. Massoud, R.; Hadiani, M.R.; Khosravi Darani, K. Bioremediation of heavy metals in food industry Application of Saccharomyces cerevisiae. Electron. J. Biotechnol. 2019, 37, 56-60. [CrossRef]

16. do Nascimento, J.M.; Oliveira, J.D.; Rizzo, A.C.L.; Leite, S.G.F. Biosorption Cu (II) by the yeast Saccharomyces cerevisiae. Biotechnol. Rep. 2018, 20,31-35. [CrossRef] [PubMed]

17. Salimi, M.; Mahzounieh, M. Saccharomyces cerevisiae on Mo and Cd removal. J. Med Microbiol. Infect Dis. 2015, 3, 18-22.

18. Amirnia, S.; Ray, M.B.; Margaritis, A. Heavy metals removal from aqueous solutions using Saccharomyces cerevisiae in a novel continuous bioreactor-biosorption system. Chem. Eng. J. 2015, 264, 863-872. [CrossRef]

19. Infante, C.; Arco, D.; Angulo, E. Removal of lead mercury and nickel using the yeast Saccharomyces cerevisiae. Rev. MVZ Cordoba. 2014, 19, 4141-4149. [CrossRef]

20. Hadiani, M.R.; Khosravi-Darani, K.; Rahimifard, N.; Younesi, H. Assessment of Mercury biosorption by Saccharomyces Cerevisiae Response surface methodology for optimization of low $\mathrm{Hg}$ (II) concentrations. J. Environ. Chem. Eng. 2018, 6, 4980-4987. [CrossRef]

21. Hadiani, M.R.; Khosravi-Darani, K.; Rahimifard, N.; Younesi, H. Biosorption of low concentration levels of Lead (II) and Cadmium (II) from aqueous solution by Saccharomyces cerevisiae: Response surface methodology. Biocat. Agri. Biotechnol. 2018, 15, 25-34. [CrossRef]

22. Massoud, R.; Khosravi-Darani, K.; Sharifan, A.; Asadi, G.H. Lead Bioremoval from Milk by Saccharomyces cerevisiae. Biocat. Agri. Biotechnol. 2019, 22, 11-20. [CrossRef]

23. AOAC. Official Methods of Analysis; Association of Official Analytical Chemists: Washington, DC, USA, 2005. 
24. WHO (World Health Organization). ISO 22935-2:2009 (IDF 99-2:2009). Recommended methods for sensory evaluation. In Milk and Milk Products_SENSORY Analysis_Part 2; WHO Press, World Health Organization: Geneva, Switzerland, 2009.

25. Khan, N.; Jeong, S.; Hwang, M.; Kim, J.; Choi, S.H.; Yeong, E.; Yeon Choi, J.; Park, K.S.; Kim, K.S. Analysis of minor and trace elements in milk and yogurts by inductively coupled plasma-mass sperometry (ICP-MS). Food Chem. 2014, 147, 220-224. [CrossRef] [PubMed]

26. Goksungur, Y.; Uren, S.; Guvenc, U. Biosorption of cadmium and lead ions by ethanol treated waste baker's yeast biomass. Bioresour. Technol. 2005, 96, 103-109. [CrossRef]

27. Langmuir, I. The adsorption of gases on plane surfaces of glass, mica and platinum. J. Am. Chem. Soc. 1918, 40, 1361-1403. [CrossRef]

28. Freundlich, H.M.F. The adsorption in solutions. Chemistry 2000, 57, 385-470.

29. Zheng, X.; Wang, X.; Shen, Y.; Lu, X.; Wang, T. Biosorption and biomineralization of uranium (VI) by Saccharomyces cerevisiae-Crystal formation of chernikovite. Chemosphere 2017, 175, 161-169. [CrossRef]

30. Hlihor, R.M.; Diaconu, M.; Fertu, D.; Chelaru, C.; Sandu, I.; Tavares, T. Bioremediation of Cr (VI) polluted wastewaters by sorption on heat inactivated Saccharomyces cerevisiae biomass. Int. J. Environ. Res. 2013, 7, 581-594.

31. Fadel, M.; Hassanein, N.M.; Elshafei, M.; Mostafa, A.H.; Ahmed, M.; Khater, H.M. Biosorption of manganese from groundwater by biomass of Saccharomyces cerevisiae. HBRC J. 2017, 13, 106-113. [CrossRef]

32. Gohari, M.; Hosseini, S.; Sharifnia, S.; Khatami, M. Enhancement of metal ion adsorption capacity of Saccharomyces cerevisiae's cells by using disruption method. J. Tai. Ins. Chem. Eng. 2013, 44, 637-645. [CrossRef]

33. Parvathi, K.; Nagendran, R. Biosorption of chromium from effluent generated in chrome electroplating unit using Saccharomyces cerevisiae. Sep. Sci. Technol. 2007, 42, 625-638. [CrossRef]

34. Hatami Fard, G.; Mehrnia, M.R. Investigation of mercury removal by Micro-Algae dynamic membrane bioreactor from simulated waste water. J. Environ. Chem. Eng. 2016, 10, 25-33. [CrossRef]

35. Saber-Samandari, S.; Gazi, M. Removal of mercury (II) from aqueous solution usingchitosan-graft-Polyacrylamide Semi-IPN hydrogels. Sep. Sci. Technol. 2013, 48, 1382-1390. [CrossRef]

36. Prasanna Kumar, Y.; King, P.; Prasad, V.S. Adsorption of zinc from aqueous solution using marine green algae-Ulva fasciata sp. Chem. Eng. J. 2007, 129, 161-166. [CrossRef]

37. Ghorbani, F.; Younesi, H.; Ghasempouri, S.M.; Zinatizadeh, A.A.; Amini, M.; Daneshi, A. Application of Response Surface Methodology for Optimization of Cadmium Biosorption in an Aqueous Solution by Saccharomyces cerevisiae. Chem. Eng. J. 2008, 145, 267-275. [CrossRef]

38. Peng, Q.; Liu, Y.; Zeng, G.; Xu, W.; Yang, C.; Zhang, J. Biosorption of Copper (II) by Immobilizing Saccharomyces cerevisiae on the Surface of Chitosan-Coated Magnetic Nanoparticle from Aqueous Solution. J. Hazard. Mat. 2010, 177, 676-682. [CrossRef] [PubMed]

39. Amini, A.; Younesi, H. Biosorption of Cd (II), Ni (II) and Pb (II) from Aqueous Solution by Dried Biomass of Aspergillus niger, Application of Response Surface Methodology to the Optimization of Process Parameters. Clean Soil Air Water J. 2009, 37, 776-786. [CrossRef]

(C) 2020 by the authors. Licensee MDPI, Basel, Switzerland. This article is an open access article distributed under the terms and conditions of the Creative Commons Attribution (CC BY) license (http://creativecommons.org/licenses/by/4.0/). 